\title{
Effect Of Zinc Application On Nutrient Content And Quality Of Wheat Crop In Alluvial Soils Of Eastern UP
}

\author{
Suman Sharma ${ }^{1}$, Devashish Singh ${ }^{2}$ \\ Research Scholar, Harsishcahndra P.G. College, Botany, MGKVP, Varanasi, (U.P.),India ${ }^{1}$ \\ Professor, Botany, Harsishcahndra P.G. College, MGKVP, Varanasi (U.P.) India ${ }^{2}$
}

\begin{abstract}
The present investigation was conducted in net house with 12 levels of zinc (0, 10,20,30,40 and $50 \mathrm{~kg} \mathrm{Zn} \mathrm{/}$ ha soil application) with and 6 levels without foliar spray during Rabi season of 2019. Zinc levels had significant effect on nutrient content and uptake during investigation. The nutrient content recorded maximum with $30 \mathrm{~kg} \mathrm{Zn} \mathrm{ha}{ }^{-1}+0.5 \%$ $\mathrm{ZnSO}_{4}$ spray, whereas uptake with $30 \mathrm{~kg} \mathrm{Zn} \mathrm{ha}^{-1}+0.5 \% \mathrm{ZnSO}_{4}$ spray. Nutrient content and uptake was enhanced by zinc levels and recorded maximum with $30 \mathrm{~kg} \mathrm{~N} \mathrm{ha}^{-1}$. However, zinc uptake recorded in grain with $30 \mathrm{~kg} \mathrm{Zn} \mathrm{ha}{ }^{-1}+0.5 \%$ $\mathrm{ZnSO}_{4}$ spray was statistically at par with $40 \mathrm{~kg} \mathrm{Zn} \mathrm{ha}^{-1}+0.5 \% \mathrm{ZnSO}_{4}$ spray and $50 \mathrm{~kg} \mathrm{Zn} \mathrm{ha}^{-1}+0.5 \% \mathrm{ZnSO}_{4}$. Therefore, application of zinc @ $30 \mathrm{~kg} \mathrm{Zn} \mathrm{ha}^{-1}+0.5 \% \mathrm{ZnSO}_{4}$ spray is to be recommended to get higher nitrogen and protein content in grain.
\end{abstract}

Keywords- Zinc, Nitrogen, Wheat, Protein content

\section{INTRODUCTION}

Wheat (Triticum aestivum L.) is considered one of the most important cereal crops not only in India but also in the world and grown under diverse agro climatic conditions. Its importance comes from using its grain as a main food source for human and its straw as feed for livestock. The world production of wheat figures over 670 million tons annually [1]. The largest producer of wheat in the world is the European Union followed by China, India and United States of American [1]). The total wheat production of the world is slightly concentrated and is clear from the fact that these four producers contribute to around $60 \%$ of the total production. Zinc plays a significant role in various enzymatic and physiological activities and performs many catalytic functions in plants besides transformation of carbohydrates, chlorophyll, nitrogen metabolism, protein synthesis [2] and synthesis of tryptophan, which is precursor of indole acetic acid [3]. The bioavailability of $\mathrm{Zn}$ in cereal grains is relatively low due to the presence of anti nutritional compounds such as phytic acid and phenolic compounds [4]. Zinc mobility in phloem is relatively high, at least in wheat [5,6]. Loading of $\mathrm{Zn}$ into developing wheat grain occurs mostly in phloem with the transfer from xylem to phloem in the rachis and the peduncle [7]. Zinc is essential for all humans, animals [8] and plants [9]. It is vital for the proper functioning of the immune system and crucial for healthy growth, physical and mental development of children. Recently, micronutrient deficiencies in plants are becoming increasingly important globally. Among micronutrients, zinc deficiency affects one third of the world's population [10] and widespread in India and contributes about 50\% to $75 \%$ in pregnant women $[11,12]$ and around $40 \%$ to $75 \%$ in children $[13,14]$ showed that in $2011,1.1$ billion people were at risk of zinc deficiency due to inadequate dietary supply. Between 1992 and 2011, global risk of deficiency of $\mathrm{Zn}$ decreased from 22 to $16 \%$. The application of macro and micronutrients fertilizer in the cultivation zone may not be fulfilling the crop requirement. The alternative approach is to apply these nutrients as foliar sprays. Soil plus foliar applications of micronutrient have been reported to be equally or even more effective as soil application [16].Foliar application lead to increase in grain yield components in wheat showed increase in yield components by application of micronutrients [17]. In general zinc have main role in synthesis of proteins, enzyme activating, oxidation and revival reactions and metabolism of carbohydrates. By utilizing of fertilizers contain zinc and other micronutrients, performance on quality of crops is increasing and with shortage of this elements due to decline in plant photosynthesis and destroy RNA, amount of solution carbohydrates and synthesis of protein decreased and then performance and quality of crop will be decreased [18]. The fertilization approach is a quick and complementary strategy, which maintains and builds a pool of zinc for translocation and uptake [19]. Zinc has moderate phloem mobility [5], so its application as a foliar feed alone or as a combination of soil plus foliar application markedly increases grain zinc content [19].Furthermore, grain zinc concentration is severely affected by the availability of a physiological pool of zinc in vegetative tissues as a result of foliar application [20], the latter can substantially increase zinc concentration in wheat endosperm [20,21]. On the other hand, soil application of zinc is less 


\section{International Advanced Research Journal in Science, Engineering and Technology}

Vol. 8, Issue 7, July 2021

\section{DOI: $10.17148 /$ IARJSET.2021.8707}

effective in increasing grain zinc concentration because of poor zinc mobility and its rapid absorption in alkaline calcareous soils [2].

\section{METHOD AND MATERIALS}

The experiment was conducted with 12 treatments having zinc levels $(0,10,20,30,40,50 \mathrm{~kg} \mathrm{Zn} /$ ha soil application) and zinc + foliar spray $(0,10,20,30,40,50 \mathrm{~kg} /$ ha soil application+0.5 \%foliar application) in alluvial soil during 2019. Treatment are $\mathrm{T}_{1}-0 \mathrm{~kg} \mathrm{Zn} /$ ha soil application, $\mathrm{T}_{2}-10 \mathrm{~kg} \mathrm{Zn} /$ ha soil application, $\mathrm{T}_{3}-20 \mathrm{~kg} \mathrm{Zn} /$ ha soil application, $\mathrm{T}_{4}-$ $30 \mathrm{~kg} \mathrm{Zn} /$ ha soil application, $\mathrm{T}_{5}-40 \mathrm{~kg} \mathrm{Zn} /$ ha soil application, $\mathrm{T}_{6}-50 \mathrm{~kg} /$ ha soil application, $\mathrm{T}_{7}-0 \mathrm{~kg} \mathrm{Zn} / \mathrm{ha}$ soil application $+0.5 \%$ foliar application, $\mathrm{T}_{8}-10 \mathrm{~kg} \mathrm{Zn} / \mathrm{ha}$ soil application $+0.5 \%$ foliar application, $\mathrm{T}_{9}-20 \mathrm{~kg} \mathrm{Zn} / \mathrm{ha}$ soil application +0.5 $\%$ foliar application, $\mathrm{T}_{10}-30 \mathrm{~kg} \mathrm{Zn} / \mathrm{ha}$ soil application $+0.5 \%$ foliar application, $\mathrm{T}_{11}-40 \mathrm{~kg} \mathrm{Zn} /$ ha soil application $+0.5 \%$ foliar application, $\mathrm{T}_{12}-50 \mathrm{~kg} \mathrm{Zn} /$ ha soil application $+0.5 \%$ foliar application. Soil moisture was maintained the field capacity by regular weighing the pots. Irrigation was given throughout the experiment period to keep the soil moist. At maturity clean plants were harvested by cutting at above the soil surface by using a stainless steel scissors. The dried top samples were then finely ground in a grinder for laboratory analysis. Total $\mathrm{N}$ and protein content was determined by semi micro-kjeldhal method and plant samples were digested with di-acid method [22].Total phosphorous and potassium in plant digest were determined by Vanadomolybdate yellow colour method and flame photometer method [23].

\section{RESULTS AND DISCUSSION}

\subsection{Nitrogen content in grain $(\%)$}

Critical assessment of data (Table 1) revealed that zinc levels proved significant improvement in nitrogen content in grain during both years of study. Maximum nitrogen content in grain was noted with treatment $\mathrm{T}_{10}\left(30 \mathrm{~kg} \mathrm{Zn} \mathrm{ha}^{-1}+0.5\right.$ $\% \mathrm{ZnSO}_{4}$ spray) as $1.71 \%, \mathrm{~T}_{9}\left(20 \mathrm{~kg}\right.$ soil $\mathrm{Zn} \mathrm{ha}^{-1}+0.5 \% \mathrm{ZnSO}_{4}$ spray) as $1.62 \%, \mathrm{~T}_{8}\left(10 \mathrm{~kg} \mathrm{soil} \mathrm{Zn} \mathrm{ha}{ }^{-1}+0.5 \% \mathrm{ZnSO}_{4}\right.$ spray) as $1.58 \%$ and minimum with control $\mathrm{T}_{1}\left(0 \mathrm{~kg}\right.$ soil $\left.\mathrm{Zn} \mathrm{ha}^{-1}\right)$ as $1.54 \%$. However, treatments receiving foliar application of zinc with and without basal dose proved superiority over control $\mathrm{T}_{1}\left(0 \mathrm{~kg}\right.$ soil Zn ha- $\left.{ }^{-1}\right)$.

\subsection{Phosphorous content in grain (\%)}

It is clear from the data (Table 1) that $\mathrm{P}$ content in grain was not affected significantly owing to zinc levels, maximum phosphorus content $(0.244 \%)$ was recorded with treatment $\mathrm{T}_{10}\left(30 \mathrm{~kg}\right.$ soil $\mathrm{Zn} \mathrm{ha}{ }^{-1}+0.5 \% \mathrm{ZnSO}_{4}$ spray) followed by $\mathrm{T}_{9}$ (20 $\mathrm{kg}$ soil Zn ha-1 $+0.5 \% \mathrm{ZnSO}_{4}$ spray) as $0.683 \%, \mathrm{~T}_{8}\left(10 \mathrm{~kg}^{-1}\right.$ soil $\mathrm{Zn} \mathrm{ha}^{-1}+0.5 \% \mathrm{ZnSO}_{4}$ spray) as $0.567 \%$ and minimum with control $\mathrm{T}_{1}\left(0 \mathrm{~kg}\right.$ soil $\left.\mathrm{Zn} \mathrm{ha}^{-1}\right)$ as $0.540 \%$. The results showed that increasing the $\mathrm{Zn}$ rates in the form of zinc sulphate also increased the NPK uptake by wheat crop, over control and highest uptake was observed with $16 \mathrm{~kg} \mathrm{Zn} \mathrm{ha}^{-1} \mathrm{combined}$ with recommended NPK.

\subsection{Potassium content in grain $(\%)$}

It was observed that the data(Table 1) that potassium content in grain was significantly influenced by levels of zinc and

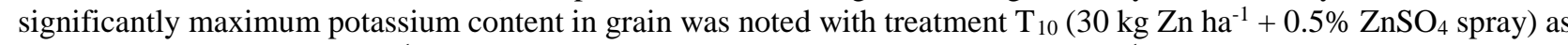
$0.244 \%, \mathrm{~T}_{9}\left(20 \mathrm{~kg}\right.$ soil $\mathrm{Zn} \mathrm{ha}^{-1}+0.5 \% \mathrm{ZnSO}_{4}$ spray) as $0.234 \%, \mathrm{~T}_{8}\left(10 \mathrm{~kg}\right.$ soil Zn ha ${ }^{-1}+0.5 \% \mathrm{ZnSO}_{4}$ spray) as $0.229 \%$ and minimum potassium content in grain control with $\mathrm{T}_{1}\left(0 \mathrm{~kg}\right.$ soil $\left.\mathrm{Zn} \mathrm{ha}{ }^{-1}\right)$ as $0.193 \%$.

\subsection{Protein content in grain $(\%)$}

Application of zinc levels treatments had marked effect on protein content of grains, all zinc levels treatments were at par to each other but proved significantly superiority over control. Maximum protein content was recorded with treatment $\mathrm{T}_{10}\left(30 \mathrm{~kg} \mathrm{Zn} \mathrm{ha}{ }^{-1}+0.5 \% \mathrm{ZnSO}_{4}\right.$ spray) as $10.69 \%, \mathrm{~T}_{9}\left(20 \mathrm{~kg}\right.$ soil Zn ha ${ }^{-1}+0.5 \% \mathrm{ZnSO}_{4}$ spray) as $9.94 \%, \mathrm{~T}_{8}$ $\left(10 \mathrm{~kg}\right.$ soil $\mathrm{Zn} \mathrm{ha}{ }^{-1}+0.5 \% \mathrm{ZnSO}_{4}$ spray) as $9.65 \%$ and minimum protein content was recorded with control $\mathrm{T}_{1}(0 \mathrm{~kg}$ soil $\left.\mathrm{Zn} \mathrm{ha}^{-1}\right)$ as $8.98 \%$. However, application of treatment $\mathrm{T}_{10}\left(30 \mathrm{~kg} \mathrm{Zn} \mathrm{ha}^{-1}\right.$ soil $+0.5 \% \mathrm{ZnSO}_{4}$ spray) proved superiority over control $\mathrm{T}_{1}\left(0 \mathrm{~kg}\right.$ soil $\left.\mathrm{Zn} \mathrm{ha}{ }^{-1}\right)$.

However, each zinc levels at par with each other but significantly superior over control. Applied zinc might have enhanced synthesis of proteins, nucleic acid and utilization of NPK present in soil which favoured greater absorption and translocation of nutrients to different plant parts resulting into higher concentration of macro and micro especially $\mathrm{N}$ and zinc. The protein content and protein yield being the function of nitrogen content and its uptake also increased with increase in nitrogen content. These results are in close conformity with the findings of [24,25,26.27,28].

The results revealed that foliar Zn application significantly increased protein in wheat grains compared with no $\mathrm{Zn}$ application in both seasons. Highest protein and $\mathrm{Zn}$ content in wheat grains was achieved with foliar $\mathrm{Zn}$ spray content in both seasons. This result is in good agreement with the studies in wheat in which grain $\mathrm{Zn}$ concentration was increased by foliar $\mathrm{Zn}$ application up to three times compared with no $\mathrm{Zn}$ application [29.30.31,32]. The positive effect of $\mathrm{Zn}$ foliar application on increasing grain protein content was reported by [33] and [34]. In this context [8] reported that one 


\section{International Advanced Research Journal in Science, Engineering and Technology}

Vol. 8, Issue 7, July 2021

\section{DOI: $10.17148 /$ IARJSET.2021.8707}

of the well-documented functions of $\mathrm{Zn}$ is related to its effect on protein synthesis and protein functions. Also, [35] reported that there is a close positive correlation between grain protein and $\mathrm{Zn}$ concentration. [36].

\section{CONCLUSION}

The results concluded that all the treatments of soil and foliar applied zinc affected significantly $(\mathrm{P}<0.05)$ total nitrogen, phosphorous, potassium and protein content in wheat. Application of $30 \mathrm{~kg} \mathrm{Zn} \mathrm{ha}{ }^{-1}$ soil $+0.5 \% \mathrm{ZnSO}_{4}$ spray produced maximum nitrogen content and protein content closely followed by Foliar applied Zinc $0.5 \%$ with $40 \mathrm{~kg} \mathrm{Zn} \mathrm{ha}^{-1}$ as a basal dose.

Table.1. Effect of zinc levels on total nitrogen content (\%), phosphorous content (\%) potassium content (\%) and protein content in wheat grain

\begin{tabular}{|c|c|c|c|c|}
\hline \multirow{2}{*}{ Treatment } & $\begin{array}{c}\text { Nitrogen } \\
\text { content }\end{array}$ & $\begin{array}{c}\text { Phosphor } \\
\text { ous } \\
\text { content }\end{array}$ & $\begin{array}{c}\text { Potassium } \\
\text { content }\end{array}$ & $\begin{array}{c}\text { Protein } \\
\text { Content }\end{array}$ \\
\cline { 2 - 5 } & $\mathbf{( \% )}$ & $\mathbf{( \% )}$ & $\mathbf{( \% )}$ & $\mathbf{( \% )}$ \\
\hline $\mathbf{T}_{\mathbf{1}}$ & 1.54 & 0.540 & 0.193 & 8.98 \\
\hline $\mathbf{T}_{\mathbf{2}}$ & 1.54 & 0.617 & 0.228 & 9.42 \\
\hline $\mathbf{T}_{\mathbf{3}}$ & 1.55 & 0.627 & 0.235 & 9.60 \\
\hline $\mathbf{T}_{\mathbf{4}}$ & 1.58 & 0.640 & 0.240 & 9.90 \\
\hline $\mathbf{T}_{\mathbf{5}}$ & 1.69 & 0.603 & 0.243 & 10.40 \\
\hline $\mathbf{T}_{\mathbf{6}}$ & 1.67 & 0.580 & 0.246 & 10.35 \\
\hline $\mathbf{T}_{\mathbf{7}}$ & 1.47 & 0.577 & 0.202 & 9.21 \\
\hline $\mathbf{T}_{\mathbf{8}}$ & 1.58 & 0.567 & 0.229 & 9.65 \\
\hline $\mathbf{T}_{\mathbf{9}}$ & 1.62 & 0.683 & 0.234 & 9.94 \\
\hline $\mathbf{T}_{\mathbf{1 0}}$ & 1.71 & 0.690 & 0.244 & 10.69 \\
\hline $\mathbf{T}_{\mathbf{1 1}}$ & 1.71 & 0.667 & 0.243 & 10.31 \\
\hline $\mathrm{SEm} \pm$ & 1.67 & 0.660 & 0.242 & 10.40 \\
\hline $\mathrm{CD}($ at 5\%) & 0.07 & 0.021 & 0.011 & 0.29 \\
\hline
\end{tabular}

Figure 1: Effect of zinc levels on total nitrogen content $(\%)$ in wheat grain

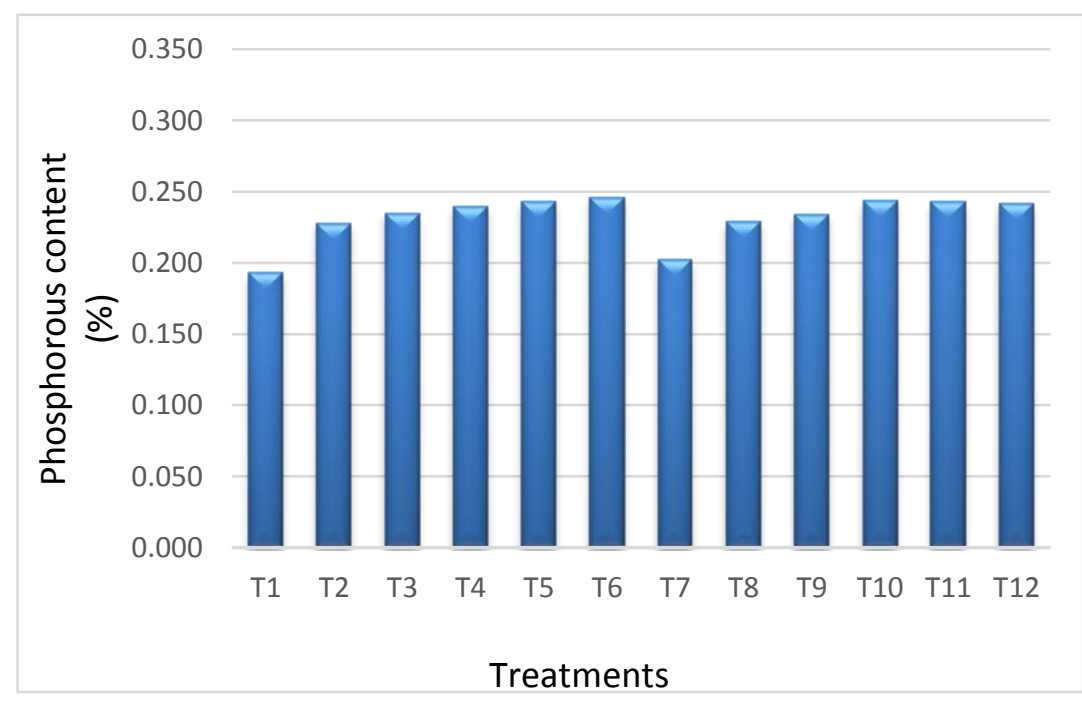

Figure 2: Effect of zinc levels on total phosphorus content $(\%)$ in wheat grain 


\section{International Advanced Research Journal in Science, Engineering and Technology}

Vol. 8, Issue 7, July 2021

\section{DOI: $10.17148 /$ IARJSET.2021.8707}

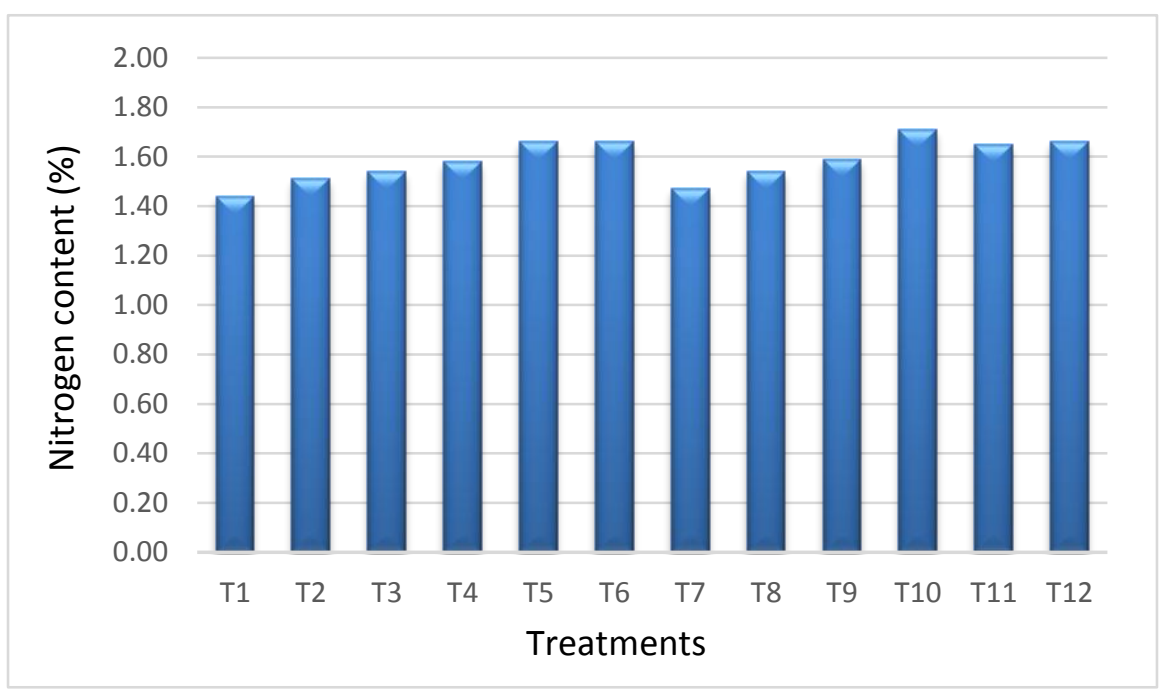

Figure 3: Effect of zinc levels on total potassium content (\%) in wheat grain

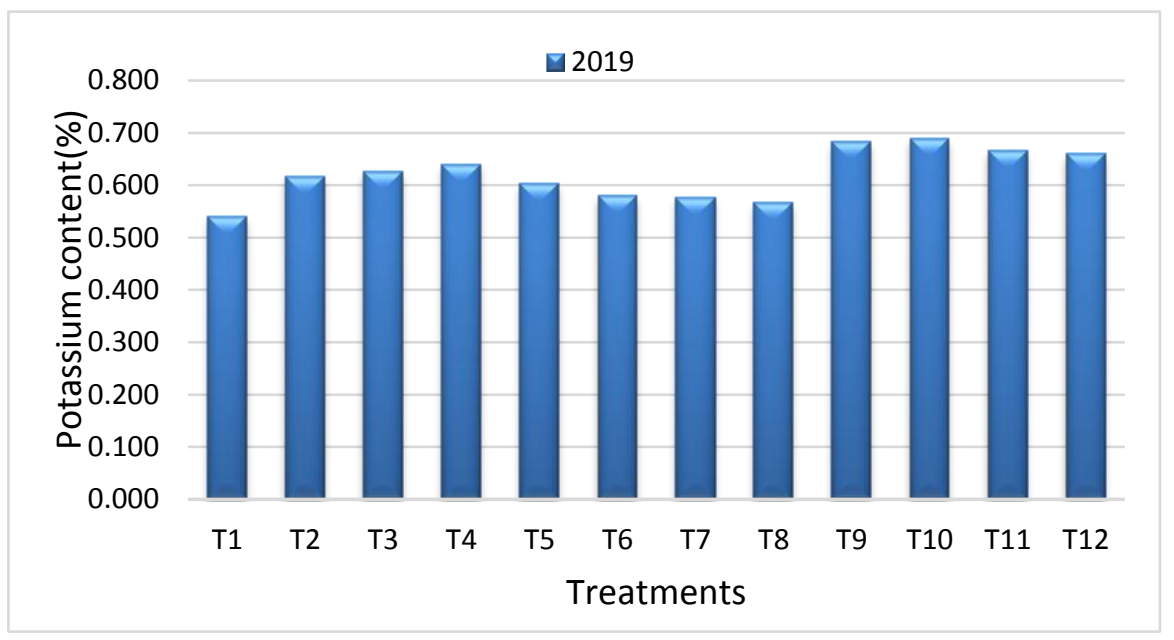

\section{REFERENCES}

1. Directorate of Wheat Research (DWR), Vision 2030. Indian Council of Agricultural Research, New Delhi, pp-1-30, 2019.

2. B. J. Alloway. "Zinc in Soils and Crop Nutrition", 2nd Edn. Brussels: IZA and IFA, 23-26, 2008.

3. C.Tsui. "The effect of zinc on water relation and osmotic pressure of the plant." American Journal of Botany, 35, 309-311, 1988.

4. R.M.Welch and R.D. Graham." Breeding for micronutrients in staple food crops from a human nutrition perspective." Journal of Experimental Botany, 55: 353-364, 2004

5. B.S. Haslett, R.J. Reid and Z. Rengel. "Zinc mobility in wheat: uptake and distribution of zinc applied to leaves or roots." Annals of Botany, 87, 379-386, 2001.

6. O.Riesen and U. Feller."Redistribution of nickel, cobalt, manganese, zinc, and cadmium via the phloem in young and maturing wheat." Journal of Plant Nutrition, 28, 421-430, 2005.

7. J.N.Pearson, Z. Rengel, C.F. Jenner, R.D." Graham Transport of zinc and manganese to developing wheat grains.” Physiologia Plantarum.; 95:449455 .

8. M.R.Broadley., P.J. White., Hammond J.P., Zelko I. and Lux A. "Zinc in plants." New Phytologist, 173(4), 677-702, 2007.

9. A.S.Prasad. "Zinc in human health: effect of zinc on immune cells." Molecular Medicine-Cambridge Ma then New York, 14(5-6), 353-357, 2008. 10. C.Hotz and K.H. Brown. "Assessment of risk of zinc deficiency in populations and option for its control.” Food and Nutrition Bulletin, 25, 94204, 2004.

11. U.Kapil and K. Jain."Magnitude of zinc deficiency amongst under five children in India." Indian Journal of Pediatrics, 78(9), 1069-1072, 2002.

12. U.Kapil, P. Pathak, P. Singh and C. Singh."Zinc and magnesium nutritive amongst pregnant mothers of urban slum communities in Delhi: A pilot study." Indian Pediatrics, 39(4), 365-368, 2011.

13. U.Dhingra, G. Hiremath, Menon, P. Venugopal, P. Dhingra, A. Sarkar and S. Sazawal. "Zinc deficiency: descriptive epidemiology and morbidity among preschool children in Peri-urban population in Delhi, India.” Journal of Health Population Nutrition, 27(5), 632-639, 2009.

14. A.Osei, R. Houser, S. Bulusu, T. Joshi and D. Hamer. "Nutritional status of primary school children in Garhwali Himalayan villages of India." Food Nutrition Bulletin, 31(2), 221-33, 2010. 


\title{
International Advanced Research Journal in Science, Engineering and Technology
}

\author{
Vol. 8, Issue 7, July 2021
}

\section{DOI: $10.17148 /$ IARJSET.2021.8707}

15. D.B. Kumssa, Joy, J.M. Edward, E. Ander, W. Louise, J. Michael, S. D. Young, S. Walker and Broadley, R Martin."Dietary calcium and zinc deficiency risks are decreasing but remain prevalent." Scientific Reports, 5, 10974, 2015.S.

16. Firdous, B.K. Agawam, A. Kumar, A. Waded, D.K. Shah."Study of translocation pattern of zinc at different growth stages in rice." Green Farming. 7(5):1134-1137, 2016.

17. M.R.Boorboori, A.D. Eradatmand and M. Tehrani. "The Effect of Dose and Different Methods of Iron, Zinc, Manganese and Copper Application on Yield Components, Morphological Traits and Grain Protein Percentage of Barley Plant (Hordeum vulgare L.) in Greenhouse Conditions.” J Advances in Environmental Biology.; 6(2):740, 2012.

18. S.R.Mousavi, M. Galati and G. Ahmadvand."Effect of zinc and manganese foliar application on yield, quality and enrichment on potato (Solanum tuberosum L).” Asian Journal of Plant Sciences 6: 1256-1260, 2007.

19. I.Cakmak."Enrichment of cereal grains with zinc: agronomic or genetic bio-fortifications." Plant and Soil, 302, 1-17, 2008.

20. I.Cakmak, W.H. Pfeiffer and B. Mc Clafferty." Biofortification of durum wheat with zinc and iron." Cereal Chemistry, 87, 10-20, 2010a.

21. Divya R. "Effect of Azadirachta Indica in Metal Oxide Nanoparticles". International Research Journal on Advanced Science Hub, 2, 8, 2020, 105-111. doi: 10.47392/irjash.2020.102

22. Y.Zhang, R. Shi, K. M. Rezaul, F. Zhang and C. Zou." Iron and zinc concentrations in grain and flour of winter wheat as affected by foliar application." J. Agric. Food Chem. 58, 12268-12274, 2010.

23. M.L.Jackson."Soil Chemical Analysis.” Prentice Hall of India Pvt. Ltd., New Delhi, 1973.

24. D.L.Sparks."Methods of soil analysis. Part 3- Chemical Methods.” American Society of Agronomy, Inc., Soil Science Society of America, Inc. Madison Wisconsin, USA, 1996.

25. Pooja Dahiya; Roopsi Kaushik; Anil Sindhu. "An Introduction to Plant Growth Promoting Rhizobacteria, Antifungal Metabolites Biosynthesis using PRPR with reference to Pseudomonas species and It's other characteristics like Antagonistic and Biocontrolling properties". International Research Journal on Advanced Science Hub, 2, Special Issue ICAMET 10S, 2020, 95-100. doi: 10.47392/irjash.2020.205

26. HIMANSHU SEKHAR BEHERA; Bijoy kumar pany. "Soil properties of medium land rice (Oryza sativa L.) in inorganic nitrogenous fertilizers on fym combination in yield". International Research Journal on Advanced Science Hub, 3, Special Issue ICIES-2021 4S, 2021, 46-49. doi: 10.47392/irjash.2021.109

27. Peck A.W., McDonald G.K. and Graham R.D. (2008). Zinc nutrition influences the proteincomposition of flour in bread wheat (Triticum aestivum L.). Journal of Cereal Science, 47, 266-274.

28. Arunkumar S.; Arivazhagan K.; Sriramachadrasekharan M. V.. "Performance of groundnut to different soil fertility amendments in coastal sandy soil". International Research Journal on Advanced Science Hub, 2, Special Issue ICSTM 12S, 2020, 93-97. doi: 10.47392/irjash.2020.268

29. M.S.Zeidan, M. F. Mohamed and H.A. Hamouda." Effect of foliar fertilization of Fe, Mn and Zn on wheat yield and quality in low sandy soils fertility." World Journal of Agricultural Science, 6(6), 696-699, 2010.

30. T.M.Chauhan, J. Ali, S.P. Singh and S.B. Singh. "Effect of nitrogen and zinc nutrition on yield, quality and uptake of nutrients by wheat." Annals of Plant and Soil Research, 16(2), 98-101, 2014.

31. S.G.Khattak, P. J. Dominy and W. Ahmad."Effect of Zn as soil addition and foliar application on yield and protein content of wheat in alkaline soil." Journal of National Science Foundation of Sri Lanka, 43(4), 303-312, 2015.

32. V.Singh, J. Ali, S.A. Kumar and T.M. Chauhan." Productivity, nutrient uptake and economics of wheat (Triticum aestivum) under potassium and zinc nutrition." Indian journal of Agronomy, 60(3), 426-430, 2015.

33. N.Phattarakul, B. Rerkasem and L. J. Li. "Biofortification of rice grain with zinc through zinc fertilization in different countries." Plant Soil, 361: 131-141, 2012.

34. M.R.Karim, Y.Q. Zhang, R.R. Zhao, X.P. Chen, F.S Zhang and C.Q. Zou. “Alleviation of drought stress in winter wheat by foliar application of zinc, boron, and manganese.” Journal of Plant Nutrition and Soil Science, 175, 142-151, 2012.

35. Boonchuay, I. Cakmak, B. Rerkasem, and C. Prom-U-Thai. "Effect of different foliar zinc application at different growth stages on seed zinc concentration and its impact on seedling vigor in rice". Soil Science and Plant Nutrition, 59: 180-188, 2013.

36. E.Esfandiari, M. Abdoli, S. B Mousavi and B. Sadeghzadeh. "Impact of foliar zinc application on agronomic traits and grain quality parameters of wheat grown in zinc deficient soil." Indian Journal of Plant Physiology, 21(3): 263-270, 2016.

37. S.E.Seadh,M. I. El-Abady, A. M. El-Ghamry and S. Farouk."Influence of micronutrient application and nitrogen fertilization on wheat yield, quality of grain." International Journal of Biological Sciences, 9(8): 851-858, 2009.

38. E.S.El-Habbasha,E. A. Badr and E. A. Latef." Effect of zinc foliar application on growth characteristics and Grain Yield of some wheat varieties under Zn deficient sandy soil condition.” International Journal Chemtech Research, 8(6): 452-458, 2015.

39. Cakmak I., Kalayci M., Kaya Y., Torun A. A., Aydin N., Wang Y., Arisoy Z., Erdem H., Yazici A., Gokmen O., Ozturk L. and Horst W. J. (2010). Biofortification and localization of zinc in wheat grain. Journal of Agricultural Food Chemistry 58: 9092.

40. El-Dahshouri. M. F., El-Fouly M. M., Khalifa R. K. M., El-Ghany H. M. A. (2017). Effect of zinc foliar application at different physiological growth stages on yield and quality of wheat under sandy soil conditions. Agricultural Engineering International: CIGR Journal, Special issue: 193200. 165 . 